JKM (Jurnal Kebidanan Malahayati),Vol 7,No.3.Juli 2021,

ISSN (Print) 2476-8944 ISSN (Online) 2579-762X, Hal 365-370

\title{
ANALISIS PEMBERIAN MP-ASI DINI TERHADAP STATUS GIZI BAYI
}

\author{
Agustin* \\ *Program Studi D-III Kebidanan, Fakultas Kesehatan, Institut Kesehatan dan Teknologi Graha Medika \\ Email: agustinbidan08@gmail.com
}

\section{ABSTRACT THE ANALYSIS OF EARLY COMPLETION FOR INFANT NUTRITIONAL STATUS}

Background: Toddlers are a nutritionally vulnerable age group who need more nutrition because they have less nutritional intake and are at risk of experiencing malnutrition. The practice factor of giving Complementary Foods for Breastfeeding greatly affects the nutritional status of babies in the future. Most of the causes of underfive mortality are related to malnutrition or malnutrition due to inappropriate complementary feeding during infancy, such as giving Complementary Foods for Breastfeeding too early or too late. This study was conducted to determine the relationship between early complementary feeding and the nutritional status of infants in the working area of the Motoboi Kecil Health Center.

Methode: This study was conducted using a quantitative descriptive type with a cross-sectional research design. Data was collected by means of observation using a questionnaire. This research was carried out in the working area of the Motoboi Kecil Health Center Kotamobagu City from April to May 2020. The research sample was 42 people. Data analysis was carried out in the form of univariate and bivariate analysis using the ChiSquare test.

Result: Early complementary feeding had no significant effect on the nutritional status of infants in the working area of the Motoboi Kecil Health Center, the results of statistical tests proved that the P-value was 0.95 $<\alpha(0.05)$ which means that there was no relationship. which is marked between early complementary feeding and the nutritional status of infants.

Conclusion: Indirectly Complementary Foods for Breastfeeding in infants early can affect infant nutrition. Giving Complementary Foods for Breastfeeding to infants early does not have a direct significant impact or influence on their nutritional status. Mother's behavior, economic conditions, and the quality of environmental sanitation have a significant effect on the nutritional status of infants.

Suggestion: complementary foods should be given to babies after 6 months of age, however, complementary foods at that age should be given gradually. It is hoped that for further studies to conduct studies related to maternal behavior, economic conditions, and the quality of environmental sanitation on the nutritional status of infants.

Keywords: Complementary Foods For Breastfeeding, Baby Nutrition.

\section{ABSTRAK}

Latar Belakang: Balita merupakan kelompok usia rentan gizi yang membutuhkan lebih banyak gizi karena asupan nutrisinya lebih sedikit yang berisiko mengalami kekurangan gizi. Faktor praktik pemberian MP-ASI sangat mempengaruhi status gizi bayi di kemudian hari. Sebagian besar penyebab kematian balita terkait dengan malnutrisi atau malnutrisi akibat pemberian makanan pendamping ASI yang tidak tepat pada masa bayi, seperti pemberian MP-ASI terlalu dini atau terlambat.

Tujuan Penelitian ini dilakukan untuk mengetahui hubungan pemberian MP-ASI dini dengan status gizi pada bayi di wilayah kerja Puskesmas Motoboi Kecil.

Metode: Penelitian ini dilakukan dengan menggunakan jenis deskriptif kuantitatif dengan desain penelitian cross-sectional. Pengumpulan data dilakukan dengan cara observasional menggunakan alat bantu kuesioner. Penelitian ini dilaksanakan di wilayah kerja Puskesmas Motoboi Kecil Kota Kotamobagu pada bulan April sampai Mei 2020. Sampel penelitian sebanyak 42 orang. Analisis data dilakukan secara univariate dan bivariate menggunakan uji Chi-Square.

Hasil: Pemberian MPASI dini tidak berpengaruh signifikan terhadap status gizi bayi di wilayah kerja Puskesmas Motoboi Kecil, hasil uji statistik membuktikan bahwa P-value $0,95<\alpha(0,05)$ yang artinya ada tidak ada hubungan. yang ditandai antara pemberian MP-ASI dini dengan status gizi bayi.

Kesimpulan: Secara tidak langsung MP-ASI Pada bayi secara dini dapat mempengaruhi gizi bayi. Pemberian MP-ASI kepada bayi secara dini tidak memberikan dampak atau pengaruh yang signifikan secara 
langsung terhadap status gizinya.Perilaku ibu, kondisi ekonomi, dan kualitas sanitasi lingkungan berpengaruh signifikan terhadap status Gizi bayi.

Saran: MP-ASI sebaiknya diberikan kepada bayi setelah berusia lebih dari 6 bulan, namun pemberian MPASI di usia tersebut diberikan secara bertahap. Diharapkan untuk kajian selanjutnya melakukan kajian terkait perilaku ibu, kondisi ekonomi, dan kualitas sanitasi lingkungan terhadap status gizi bayi.

Kata Kunci: Makanan Pendamping ASI, Gizi Bayi

\section{PENDAHULUAN}

Balita merupakan kelompok usia rawan gizi yang membutuhkan zat gizi lebih banyak, karena asupan zat gizi yang kurang dapat berisiko mengalami kelainan gizi. Pada masa ini, pertumbuhan dan perkembangan anak berlangsung cepat, berkaitan dengan besar, jumlah dan ukuran tubuh. Perubahan yang di alami seperti perubahan pertumbuhan volume dan tinggi badan. Bayi yang gagal tumbuh banyak terjadi pada bulan ke tiga atau bulan ke empat awal kehidupan. Banyak faktor penyebab terjadinya gagal tumbuh pada anak. Salah satu nya di sebabkan karena ibu tidak menyusui bayi lagi sehingga ibu memberikan makanan pendamping ASI lebih awal (MP-ASI dini) sebelum usia 6 bulan, bayi di berikan makanan hanya ASI saja, dengan demikian ibu yang telah memberikan MP-ASI dini (< 6bulan) berarti tidak memberikan ASI eksklusif kepada bayinya (Sarly MZ, Simanjuntak, \& Suryani, 2018).

Permasalahan gizi dapat di tunjukan dengan besarnya angka kejadian gizi buruk yang menunjukkan kesehatan masyarakat indonesia terendah di ASEAN, dan menduduki peringkat ke 142 dari 170 negara. Data WHO menyebutkan bahwa indonesia tergolong negara dengan status kekurangan gizi yang tinggi pada tahun 2015 yaitu 14,5\%, (Kurdaningsih, 2018).

Angka kematian bayi (AKB) menurut hasil survei demografi dari kesehatan di indonesia (SDKI 2007), dari 30 per 1.000 kelahiran hidup pada tahun 2010, menjadi 33 per 1.000 kelahiran hidup di tahun 2012 pada tahun 2015 menjadi 23 per 1.000 kelahiran hidup, sedangkan angka kematian balita (AKABA) menurut SDKI 2012 adalah 40, AKABA di provinsi sulawesi utara menurut SDKI 2013 adalah 37 yang masih lebih rendah dari angka nasional. Dan kasus kematian ibu provinsi sulawesi utara tahun 2016 mengalami penurunan di bandingkan dengan tahun 2015, dimana pada tahun 2016 terdapat 54 kasus menurun di bandingkan dengan tahun 2015 sebanyak 71 kasus kematian ( DINKES SULUT, 2017).

Kematian bayi di Kota Kotamobagu hingga saat ini masih sangat fluktuatif, pada tahun 2017 jumlah kematian bayi tercatat sebanyak 13 jiwa dan
$46 \%$ diantaranya disebabkan oleh asfiksia. penyakit lainya sebanyak $38,4 \%$, BBLR sebanyak $7,69 \%$, Dan infeksi sebanyak 7,69\%. Kemudian pada tahun 2018 tercatat sebanyak 9 jiwa, 70\% diantaranya di akibatkan oleh infeksi, 10\% diakibatkan penyakit lainnya sebanyak 20\%, ( DINKES SULUT, 2017).

Sebagian besar penyebab kematian balita berkaitan dengan gizi kurang atau gizi buruk akibat pemberian MP-ASI yang tidak baik pada masa bayi, seperti pemberian makanan pendamping ASI yang terlalu dini atau terlambat serta makanan pendamping ASI yang tidak memenuhi kebutuhan zat gizi secara kualitas maupun kuantitas dan tidak higenis, (Wardani, 2018). Faktor utama yang mempengaruhi pemberian MP-ASI terhadap berat badan bayi usia 6-24 bulan adalah usia awal dan jenis pemberian MP-ASI yang di berikan oleh orang tua (Wilujeng, Sariati, \& Pratiwi, 2017). Kekeliruan dalam pemberian jenis pemberian MP-ASI pada bayi akan berdampak pada berat badan yang tidak normal dari. Pentingnya pemberian ASI Ekslusif bagi bayi untuk memenuhi kebutuhan gizi dan kesehatan anak (Kurdaningsih, 2018).

Faktor praktik pemberian MP-ASI sangat berpengaruh pada status gizi gizi bay pada mas mendatang. Semakin baik praktik pemberian makanan pendamping ASI (MP ASI) maka status gizi pada tumbuh kemabng bayi juga akan semakin baik (Kurdaningsih, 2018).Berdasarkan hasil observasi data sekunder Puskesmas Motoboi Kecil Kecamatan Kota Kotamobagu pada tanggal 20 November Tahun 2019 di dapatkan bahwa balita yang mendapatkan pola pemberian MP-ASI Yang baik masih sangat rendah yaitu hanya sebanyak 72 balita, jika dibandingkan Pada Tahun 2018 menurun sebanyak $18, \%$. Penelitian ini dilakukan untuk mengetahui hubungan pemberian MP-ASI dini dengan status gizi pada bayi di wilayah kerja Puskesmas Motoboi Kecil.

\section{METODOLOGI PENELITIAN}

Penelitian ini dilakukan menggunakan jenis Kuantitatif Deskriptif dengan rancang bangun crosssectional study menggunakan pendekatan observational analititk dimana pengumpulan data dilakukan pada waktu yang sama. Penelitian ini di 
JKM (Jurnal Kebidanan Malahayati),Vol 7,No.3.Juli 2021,

ISSN (Print) 2476-8944 ISSN (Online) 2579-762X, Hal 365-370

laksanakan di wilayah kerja Puskesmas Motoboi Kecil Kota Kota Mobagu, pada bulan April sampai dengan Mei 2020. Populasi dalam penelitian ini berjumlah 169 orang bayi, sampel yang di gunakan sebanyak 42 bayi, sampel penelitian di tentukan berdasarkan ketentuan proyeksi antara 20\%-25\%, karena populasi lebih dari 100 orang, Analisis data dilakukan dalam bentuk analisis univariate dan bivariate menggunakan uji Chi-Square, (Arikunto, 2010).

\section{HASIL DAN PEMBAHASAN}

Analisis Univariat

Tabel 1.

Distribusi karakteristik Responden berdasarkan status gizi bayi di Puskemas Motoboi Kecil Kotamobagu, Tahun 2020

\begin{tabular}{lcc}
\hline Kategori & Jumlah Responden & Presentasi (\%) \\
\hline Gizi Baik & 38 & 90,8 \\
Gizi Lebih & 0 & 0 \\
Gizi Kurang & 4 & 9,5 \\
\hline \multicolumn{1}{c}{ Total } & 42 & 100 \\
\hline
\end{tabular}

Tabel 1. menunjukkan bahwa status gizi bayi di wilayah kerja Puskesmas Motoboi kecil sebagian besar menyandang status gizi baik, hal tersebut di dapatkan dari hasil analisis 42 responden sampel yang berada di wilayah kerja Puskesmas Motoboi kecil. Dan 9,5\% diantaranya merupakan bayi dengan status gizi kurang.

Tabel 2.
Distribusi karakteristik responden berdasarkan pemberian MP ASI di Puskesmas Motoboi Kecil Kotamobagu, Tahun 2020

\begin{tabular}{ccc}
\hline $\begin{array}{c}\text { Pemberian MP } \\
\text { ASI }\end{array}$ & $\begin{array}{c}\text { Jumlah } \\
\text { Responden }\end{array}$ & $\begin{array}{c}\text { Presentasi } \\
(\%)\end{array}$ \\
\hline$<6$ Bulan & 1 & 2,7 \\
$>$ 6 Bulan & 41 & 95,2 \\
\hline Total & 42 & 100 \\
\hline
\end{tabular}

Berdasarkan data pada Tabel 3. Dapat di ketahui bahwa bayi diwilayahh kerja Puskesmas Motobi kecil sebagian besarnya mendapatkan MPAsi setelah berumur lebih dari 6 bulan. Sedangkan bayi yang mendapatkan MP-ASI sebelum umur 6 bulan atau kurang dari 6 bulan hanya sebanyak $2,7 \%$ dari total populasi sampel yang di analisis (42) orang.

\section{Analisis Bivariat}

Hasil analisis data padaTabel 3. Dapat diketahui bahwa pemberian MP-ASI secara dini tidak memiliki dampak yang signifikan terhadap status gizi bayi di wilayah kerja puskesmas Motoboi Kecil. Sebagian besar bayi $90 \%$ bayi yang tidak di berikan MP-ASI dini memiliki status gizi yang baik, sedangkan terdapat 1 orang bayi yang di berikan MP-ASI dan mengalami gizi kurang. Berdasarkan hasil uji statistik hal tersebut terbukti dari nilai $P$ Value sebesar $0,95<\alpha(0,05)$, yang berarti bahwa tidak terdapat hubungan yang signifikan antarapemberian MP-ASI dini dengan status gizi bayi.

Tabel 3.

Distribusi hubungan MP-ASI dini dengan statsu gizi bayi di Puskesmas Motoboi Kecil Kotamobagu, Tahun 2020

\begin{tabular}{|c|c|c|c|c|c|}
\hline \multirow{3}{*}{ Status Gizi } & \multicolumn{2}{|c|}{ Pemberian MP-ASI Dini } & \multirow{2}{*}{ Total } & \multirow{2}{*}{ Presentasi } & \multirow{2}{*}{$\begin{array}{c}P \\
\text { Value }\end{array}$} \\
\hline & Tidak & $\mathrm{Ya}$ & & & \\
\hline & $\mathrm{N}$ & $\mathrm{N}$ & $\mathrm{N}$ & $\%$ & \\
\hline Baik & 38 & 0 & 38 & $90,47 \%$ & \\
\hline Cukup & 0 & 0 & 0 & $0,0 \%$ & 0,95 \\
\hline Kurang & 3 & 1 & 4 & $7,1 \%$ & \\
\hline Total & 41 & 1 & 42 & $100 \%$ & \\
\hline
\end{tabular}

\section{PEMBAHASAN}

\section{Status Gizi}

Status gizi bayi di wilayah kerja Puskesmas Motoboi kecil sebagian besar menyandang status gizi baik. Bayi yang memiliki status gizi baik dapat diketahui pada usia 6-24 bulan yang mendapat MPASI. Tumbuh kembang seorang bayi sangat bergantung pada status gizinya, pemenuhan kebutuhan gizi secara benar dan baik akan mencapai tumbuh kemang anak yang sempurna. Pada dasarnya bayi dan anak yang mengalami kurang akan berdampak pada gangguan pertumbuhan dan perkembangannya yang akan 
terus berkelanjutan apabila tidak segera di atasi, (Lestari, Lubis, \& Pertiwi, 2014).

Program peningkatan status gizi bayi dan anak umur 0-24 bulan dimulai dari perbaikan pola perilaku masyarakat terkait asupan makanan pada bayi sebagai bentuk upaya perbaikan gizi pada anak di bawah 2 tahun secara keseluruhan. Rendahnya pengetahuan terkait pola pemberian makanan bagi bayi dan anak dibawah 2 tahun, menjadi faktor utama terjadinya status kekurangan gizi, (Widyawati, Febry, \& Destriatania, 2016).

\section{Pemberian MP ASI}

Perilaku masyarakat terkait Pemberian MPASI bagi bayi diwilayah kerja Puskesmas Motoboi kecil masih kurang dipahami, sehingga ibu yang memiliki bayi masih kurang antusias untuk memberi MP-ASI kepada bayi secara baik dan benar, selain itu asupan asi yang baik juga belum begitu diketahui oleh ibu yang memiliki bayi. Pemberian MP-ASI kepada bayi haruus disesuaikan dengan kandungan gizi yang ada dalam kandungan ASI serta harus bersih dan memiliki rasa dan tekstur yang menarik, MP-ASI akan membantu ASI untuk melengkapi kebutuhan gizi bayi secara bertahap.

MP-ASI merupakan salah satu makanan diluar ASI yang diberikan kepada bayi pada saat usia> 6 bulan dan $\leq 6$ bulan sebagai bentuk pemenuhan kebutuhan gizi bayi, dan bukan sebagai pengganti gizi, (Widyawati, Febry, \& Destriatania, 2016). Program MP-ASI yang cukup baik dari segi kuantitas dan kualitas sangat berdampak pada tumbuh kembang anak, serta mempengaruhi tingkat kecerdasan anak. Seiring bertambahnya umur bayi sejalan dengan bertambahnya kebutuhan asupan gizi yang di butuhkan, $60 \%$ kebutuhan gizi pada bayi dapat terpenuhi dengan pemberian ASI, untuk memenuhi kebutuhan gizi bayi maka dapat diberikan MP-ASI yang berkualitas (Mufida, Widyaningsih, \& Maligan, Basic Principles of Complementary Feeding for Infant 6 - 24 Months: A Review, 2015).

\section{Hubungan Pemberian MP ASI Dini Terhadap Status Gizi Bayi}

MP-ASI yang diberikan secara dini tidak memiliki dampak yang signifikan terhadap status gizi bayi di wilayah kerja puskesmas Motoboi Kecil.Hasiluji statistik membuktikan bahwa nilai $P$ Value yang diperoleh sebesar $0,95<\alpha(0,05)$, yang berarti bahwa tidak terdapat hubungan yang signifikan antara pemberian MP-ASI dini dengan status gizi bayi.

Pemerian ASI pada umumnya dapat di lakukan pada kurun waktu 4-6 bulan pertama saja, karena setelah waktu tersebut ASI yang di produksi ibu akan berkurang jumlahnya, sehingga peranan makanan pendamping sangat penting, bayi yang berusia 6-9 bulan di beri makanan pendamping ASI sebanyak 1-2 kali sehari, dengan komponen bubur, saat bayi berusia 12-24 bulan dapat diberi makanan pendamping ASI sekurang-kurangnya 3 kali sehari, karena pada mas tersebut jumlah ASI akan sangat berkurang, dengan komponen $1 / 2$ makanan berupa bubur dan $1 / 2$ makanan orang dewasa, dan mulai di perkenalkan ragam makanan yang bergizi lainnya, (Mufida, Widyaningsih, \& Maligan, 2015)

Terjadinya stunting pada anak khususnya di wilayah pedesaan dapat dipengaruhi oleh faktor pendidikan ibu, ekonomi, ASI Ekslusif, serta riwayat penyakit yang diderita oleh anak atau bayi. (Sarly MZ, Simanjuntak, \& Suryani, 2018). Pemberian MPASI pada bayi wilayah kerja Puskesmas Motoboi Kecil tidak menjadi faktor utama penyebab terjadinya gizi kurang pada bayi usia 6-24 bulan.

Pemberian makanan pendamping asi (MPASI) tidak menjadi faktor pemicu terjadinya status gizi baik atau buruk pada bayi atau keduanya tidak memiliki hubungan yang kuat saling mempengaruhi (Dewi \& Mu'minah, 2020). Pemberian MP-ASI pada tingkat usia tertentu pada bayi tidak memiliki linearitas yang berarti dengan tingkat risiko terjadinya stunting atau gizi buruk pada bayi atau pada anak (Nai, Gunawan, \& Nurwanti, 2014).

Rendahnya tingkat perilaku ibu untuk melakukan MP-ASI dini pada bayi menjadi hal yang tepat atau menjadi faktor penyebab rendahnya bayi atau anak yang mengalami gizi buruk di wilayah kerja Puskesmas Motoboi Kecil.Faktor pendapatan keluarga menjadi faktor utama yang menyebabkan terjadinya gangguan pada status gizi dibandingkan dengan faktor pendidikan orang tua, (Rompas, Punuh, \& Kapantov, 2016).

Persoalan kemiskinan dan sanitasi lingkungan yang tidak baik menjadi penyebab terjadinya permasalahan status gizi dan penyakit infeksi pada suatu keluarga masalah gizi dan penyakit infeksi, sementara pemberian MP-ASI tidak dapat mempengaruhi status gizi bayi, (Puspitawati \& Sulistyarini, Sanitasi Lingkungan yang tidak Baik Mempengaruhi Status Gizi pada Balita, 2013).

Secara tidak langsung masalah gizi disebabkan oleh sanitasi rumah Tumbuh kembang seorang anak sangat ditunjang oleh keadaan sanitasi rumah yang baik (Soetjiningsih, 2012).Penyakit infeksi yang timbul pada seorang anak disebabkan oleh salah satu faktor yaitu sanitasi lingkungan yang kurang baik yang berdampak langsung pada status gizi seorang anak, 


\section{JKM (Jurnal Kebidanan Malahayati),Vol 7,No.3.Juli 2021, ISSN (Print) 2476-8944 ISSN (Online) 2579-762X, Hal 365-370}

salah satunya yaitu keadaan rumah ( Putri \& Sukandar, 2012).Kemiskinan dan sanitasi yang buruk merupakan faktor utama terjadinya permasalahan gizi dan infeksi (Puspitawati, Sanitasi Lingkungan Yang Tidak Baik Memengaruhi Status Gizi Pada Balita, 2013).

Tidak adanya dampak dari pemberian MPASI dini terhadap status gizi bayi diwilayah kerja Puskesmas Motobi kecil bukan hanya di sebabkan oleh tidak adanya ibu yang melakukan MP-ASI dini namun juga dampak dari kedaan ekonomi rumah tangga dan sanitasi lingkungan rumah ibu khususnya lingkungan tumbuh kembang anak juga sudah baik. Kedaan ketimpangan perekonomian masyarakat Kota Kotamobagu terhitung sejak tahun 2018 hingga 2020 terbukti selalu berkurang hingga menghampiri angka 0 yaitu $0.389-0.322$ atau mengalami penurunan hingga $12 \%$ dan merupakan daerah ke 4 terbaik penurunan ketimpangan ekonomi masyarakat di wilayah sulawesi utara, (BPS Kota Kotamobagu, 2021).

\section{SIMPULAN}

Pemberian MP-Asi kepada anak usia antara 6-24 bulan tidak memiliki dampak atau pengaruh yang besar atau signifikan terhadap status gizi bayi atau anak 6-24 bulan dalam proses tumbuh kembangnya, namun faktor-faktor yang dapat berpengaruh baik secara langsung maupun tidak langsung yaitu, perilaku ibu, keadaan ekonomi keluarga, serta tingkat kualitas sanitasi lingkungan tempat tumbuh kembang bayi atau anak di usia 624 bulan.

\section{SARAN}

MP-ASI sebaiknya diberikan kepada bayi setelah berusia lebih dari 6 bulan, namun pemberian MP-ASI di usia tersebut diberikan secara bertahap. Diharapkan untuk kajian selanjutnya melakukan kajian terkait perilaku ibu, kondisi ekonomi, dan kualitas sanitasi lingkungan terhadap status gizi bayi.

\section{DAFTAR PUSTAKA}

DINKES SULUT. (2017). Profil Kesehatan Sulawesi Utara. Manado: Dinas Kesehatan Sulawesi Utara.

Putri, D. S., \& Sukandar, D. (2012). Keadaan Rumah, Kebiasaan Makan, Status Gizi, Dan Status Kesehatan Balita Di Kecamatan Tamansari, Kabupaten Bogor. Journa; Of Nutrition and Food, 7(3), 163-168.

Arikunto, S. (2010). Prosedur Penelitian Suatu Pendekatan Praktik. Jakarta: Rineka Cipta.
BPS Kota Kotamobagu. (2021, Maret 18). Gini Rasio Sulawesi Utara menurut Kabupaten/Kota 2018-2020. (Badan Pusat Statistik) Dipetik Januari 5, 2021, dari https://kotamobagukota.bps.go.id/statictable. html

Dewi, S., \& Mu'minah, I. (2020). Pemberian Mp- Asi Tidak Berhubungan Dengan Kejadian Stunting Pada Anak Usia 1- 3 Tahun Di Wilayah Kerja Puskesmas Sumbang I Kabupaten Banyumas. INFOKES, 10(1), 510.

Kurdaningsih, S. V. (2018). Hubungan Pemberian Makanan Pendamping Asi Dengan Status Gizi Pada Balita Usia 6-24 Bulan. Jurnal IImiah Multi Science Kesehatan, 9(1), 109115.

Lestari, M. U., Lubis, G., \& Pertiwi, D. (2014). Hubungan Pemberian Makanan Pendamping Asi (MP-ASI) dengan Status Gizi Anak Usia 1-3 Tahun di Kota Padang. Jurnal Kesehatan Andalas, 3(2), 188-190.

Mufida , L., Widyaningsih, T. D., \& Maligan, J. M. (2015). Basic Principles of Complementary Feeding for Infant 6 - 24 Months: A Review. Jurnal Pangan dan Agroindustri , 1646-1651.

Mufida, L., Widyaningsih, T. D., \& Maligan, J. M. (2015). Basic Principles of Complementary Feeding for Infant 6 - 24 Months: A Review. Jurnal Pangan dan Agroindustri, 3(4), 16461651.

Nai, H. M., Gunawan, I. A., \& Nurwanti, E. (2014). Complementary feeding practices were not risk factors of stunting among children 6-23 months. Indonesian Journal Of Nutrition and Dietetics, 2(3), 126-139.

Puspitawati, N. (2013). Sanitasi Lingkungan Yang Tidak Baik Memengaruhi Status Gizi Pada Balita. Jurnal STIKES, 6(1), 46-52.

Puspitawati, N., \& Sulistyarini, T. (2013). Sanitasi Lingkungan yang tidak Baik Mempengaruhi Status Gizi pada Balita. Jurnal Stike, 6(1), 74-83.

Rompas, K. F., Punuh, M. I., \& Kapantov, N. H. (2016). Hubungan Antara Sosial Ekonomi Keluarga Dengan Status Gizi Pada Pelajar Di Smp Wilayah Kecamatan Malalayang 1 Kota Manado. PHARMACON Jurnal IImiah Farmasi, 5(4), 225-233.

Sarly MZ, R. B., Simanjuntak, B. Y., \& Suryani, D. (2018). Early Complementary Feeding of Breast Milk and nutritional status (Height for Age index) 4-7 month in Districts Ratu Samban Bengkulu City) . Jurnal AcTion: Aceh Nutrition Journal, 3(2), 103-109. 
Soetjiningsih. (2012). Tumbuh Kembang Anak. Jakarta: Buku Kedokteran EGC.

Wardani, G. K. (2018). Ubungan Pemberian Makanan Pendamping Asi Dengan Status Gizi Bayi Usia 6-24 Bulan. Jurnal IImiah Media Husada, 7(2), 70-75.

Widyawati, Febry, F., \& Destriatania, S. (2016). Analysis Complementary Feeding And Nutritional Status Among Children Aged 12-
24 Months In Puskesmas Lesung Batu,Empat Lawang. Jurnal Ilmu Kesehatan Masyarakat, 7(2), 139-149.

Wilujeng, C. S., Sariati, Y., \& Pratiwi, R. (2017). Faktor Yang Mempengaruhi Pemberian Makanan Pendamping ASI Terhadap Badan Anak Usia 6-24 Bulan di Puskesmas Cluwak Kabupaten Pati. majalah Kesehatan, 4(2), 88-95. 